\title{
The Correlates of Educated Women's Labor Force Participation in Pakistan: A Micro-Study
}

\section{Muhammad Zahir Faridi and Ayesha Rashid*}

\begin{abstract}
This study attempts to determine the factors that affect educated women's decision to participate in the labor force. Based on a field survey conducted in the district of Multan, we find that a number of factors have a positive and significant impact on women's decision to work. These include women who fall in the age groups 35-44 and 45-54, the coefficients of all levels of education, the presence of an educated husband, marital status, family structure, and family expenditure. The presence of an educated father, being an educated married woman, location, distance from the district headquarters, the husband's employment status and income, and ownership of assets significantly reduces women's labor force participation. The results of the earnings equation show that variables such as women who live in an urban area and their level of education and experience are associated with a substantial increase in earnings with each additional year. The number of children has a negative and significant impact on women's earnings. The hours-of-work model shows that age and the number of completed years of education have a positive effect on working hours, while the number of dependents and the number of hours spent on household activities have a negative effect on working hours.
\end{abstract}

Keywords: Human capital, labor force participation, earnings function, time allocation, Punjab, Pakistan.

JEL classification: D00, J21.

\section{Introduction}

Labor force participation (LFP) is the act of participating in productive activities to generate income and meet certain social requirements. In Pakistan, the labor force includes all persons aged ten or above "who are working or looking for work for cash or [in] kind, one week prior to the date of enumeration" (Ejaz, 2007). LFP analyses help determine policies for employment and human resource development. Pakistan has a relatively low LFP rate because of the small percentage of

\footnotetext{
* Department of Economics, Bahauddin Zakariya University, Multan, Pakistan.
} 
women who participate in the workforce-an issue that is of major concern for the country's development prospects.

Female labor force participation (FLFP) contributes significantly to socioeconomic development because it provides households with a second source of income and can help reduce poverty. Given that about half of Pakistan's population comprises women, it is important to analyze their role in the labor market and in economic development. Over the past few years, many studies have focused on this area and underscored the significant positive association between FLFP and economic growth (see Ejaz, 2007; Faridi, Sharif, \& Anwar, 2009; Faridi, Sharif, \& Malik, 2011).

In Pakistan, as in many other developing countries, social and cultural norms often mean that women lag behind men in many respects. While women work longer hours than men, much of their work involves care-giving and looking after the household. Gender discrimination, social and cultural restrictions, workplace location, and family responsibilities all determine women's access to the labor market. The financial pressure of poverty or looking after a large family might push women into the labor force (Kazi \& Raza, 1991), but factors such as education, training and experience serve to pull women into the labor force (Killingsworth \& Heckman, 1986; Mincer \& Polachek, 1974). Other variables such as family structure (either joint or nuclear), the education level of a woman's husband and/or parents, the availability of jobs, and workplace location are also potential determinants of FLFP (Faridi et al., 2011).

According to the Pakistan Bureau of Statistics (2012), the LFP rate has increased from 50.4 percent in 1999/2000 to 53.4 percent in 2010/11, while the employment-to-population ratio has increased from 46.8 percent $(1999 / 2000)$ to 50.4 percent $(2010 / 11)$. Although the FLFP has risen from 13.7 percent in 1999/2000 to 22.2 percent in 2010/11, women's contribution remains comparatively low vis-à-vis other South Asian countries. Women's participation rates also help us better understand the productive and reproductive roles of the female population.

The present study aims to determine why some educated women (both married and unmarried) are involved in earning activities while others are not. We analyze how various socioeconomic and demographic variables influence the participation decision of educated women in the district of Multan. Our sample consists of educated women both from rural 
and urban areas who have completed at least eight years of schooling. ${ }^{1}$ Such women are expected to be free to choose whether or not to enter the labor market. We also estimate an earnings function and hours-of-work equation for educated women to analyze which factors affect their earnings and working hours.

The study is organized as follows. Section 2 reviews the literature at a national and international level. Section 3 describes the data and methodology used, including the sample design and data collection. Section 4 gives the variables selected and model construction. Section 5 presents the results of the estimation and Section 6 provides some concluding remarks and policy recommendations.

\section{Literature Review}

Apart from studies that have looked at FLFP issues at the national and international level, a number of authors have also discussed the economic theory of the household, which is relevant in this context. Becker (1965) and Gronau (1977), both of who pioneered research in this field, explain household behavior regarding time allocation as follows: an increase in the market wage rate reduces the level of work at home and has an intermediate effect on the time spent on leisure and on market production.

In a demographic survey of Sudan (1990/91), Maglad (1998) finds that FLFP is positively related to education and own wages and negatively related to the spouse's wage, asset ownership, and the presence of small children. Amin (1994) uses household survey data for Bangladesh (for 1992) and notes that FLFP is inversely related to income, purdah (female seclusion), and the patriarchal system and positively related to marital status, education, and age. Georgellis and Wall (2005), Le (2000), and Blanchflower find that education, health, experience, family background, and marital status are all highly significant factors in women's self-employment.

Mincer (1962) investigates the factors that influence women's labor market decisions in the context of the relationship between working hours and FLFP over time. He concludes that women's decision to participate in the labor force is negatively related to spousal earnings but positively related to their own earning power. The number of children also has a positive relationship with FLFP decisions. Additionally, educational activity is a vital component of the productive life of individuals.

\footnotetext{
${ }^{1}$ This is because most rural women are likely to have completed only up to middle school.
} 
Bover and Arellano (1995) analyze the determinants of the increase in FLFP in Spain during the 1980s. They observe that the business cycle has a significant effect on participation. Moreover, FLFP increases with higher levels of education and lower birth rates. These structural factors increase women's earning potential. If the prime age does not change in the future, FLFP increases as newer cohorts replace the old ones.

Azid, Aslam, and Chaudhary (2001) examine the factors that influence FLFP in Pakistan's cottage industries. Based on data collected through a field survey in Multan, they find that FLFP has a positive relationship with the number of children in a household, women's age and education, and poverty status, but a negative relationship with the number of under-five children. The coefficient of purdah is statistically insignificant because the cottage industry-level embroidery work in which the sampled women engage is different from other fields of work.

Naqvi and Shahnaz (2002) note that the number of children in a household and the presence of a female household head are negatively linked to women's economic participation. Although women's age and education level have a positive impact on FLFP, married women are less likely to participate. Older women, better educated women, women who are household heads, and women from smaller, financially stronger urban families are more likely to choose to participate, while younger women, poorly educated women, and women from larger families are more likely to be compelled to participate in the labor market.

In a study on Ghana, Sackey (2005) finds that both primary and post-primary schooling have a positive impact on FLFP and a negative impact on fertility. In addition, the gender gap in education has narrowed over the years and it is important for government policies to ensure that the gains of female education are sustained. Education is thus an important determinant of female human capital and productive employment.

Babalola and Akor (2013) analyze the factors that affect the labor participation decision of married women aged 18-60 in Adamawa state, Nigeria. The study finds that women's level of education is positively related to their FLFP while the spouse's employment status and household size have a negative effect. This implies that government policies should target female education, which clearly enhances female human capital development and productive employment. 
Ahmad and Hafeez (2007) observe that women with a higher level of education are more likely to work for cash remuneration and to earn more per hour. Women living in joint families, women with fewer assets, and women whose husbands earn low incomes are positively associated with FLFP, while women whose husbands or parents are less educated are less likely to participate in the labor market. Factors that influence women's earnings include education, experience, training, the nature of occupation, and the distance from the central city. Their working hours are generally determined institutionally.

In her empirical study on Pakistan, Ejaz (2007) investigates the determinants of rural and urban FLFP and concludes that age, educational attainment, marital status, living in a nuclear family, fewer children, access to a vehicle, and the availability of childcare facilities increase FLFP. A larger number of children and the availability of home appliances are negatively related to FLFP.

Faridi, Sharif et al. (2009) estimate the socioeconomic and demographic determinants of FLFP and conclude that secondary and higher education, marital status, family structure, the presence of an educated spouse, and the number of children are positively related to women's participation in the workforce. Younger women (aged 15-24), women with household assets, women whose husbands are economically active, and women with children aged 0-6 are less likely to participate in the labor market.

Chaudhry, Faridi, and Anjum (2010) examine the impact of health and education on women's earnings in Vehari. They find that higher levels of education and better health and nutrition are positively related to women's earnings. Having a diploma or vocational training, however, are negatively related to earnings. Women engaged in formal employment earn less than those engaged in informal employment because they have lower-paid jobs. Women who are either married or divorced and live in an urban area earn more, while widows and single women living in a rural area earn less because they may not have permission to work outside their homes or may have fewer economic responsibilities.

Afzal and Bibi (2012) investigate the determinants of married women's FLFP in Wah Cantt. Their empirical study concludes that women's level of education, the number of children and dependents, family size, the spouse's income, monthly expenditures, the positive attitude of the spouse and family toward women working, and job satisfaction are positively associated with married women's FLFP. 
Women's age, living with a spouse, the level of satisfaction with their role as a homemaker, family-imposed job restrictions, and the presence of other household earners have a negative relationship with FLFP. In addition, the inflation rate has a large effect on married women's FLFP.

The literature clearly shows that various factors have an important effect on women's decision to participate in the labor force. This study is significant in that, unlike other comparable studies, it has used improved reporting methods to collect data on women's labor participation decisions in rural and urban Multan. It not only highlights the problems and factors behind the low FLFP but also proposes recommendations to improve women's living standards and better utilize their resources for national development. This serves as an important contribution to the economic literature.

\section{Data Sources and Methodology}

The data for this study was collected through a field survey conducted in Multan, using a simple random sampling technique. The sample consists of 300 educated women-both participating (employed) and nonparticipating (unemployed) as well as married and unmarriedrandomly selected from rural and urban areas of the district. The data was collected from the main residential areas in the north, south, east, west and central part of the selected area. The minimum criterion for being classified as "educated" was to have completed eight years of schooling.

The information on respondents and their household characteristics was collected using a questionnaire that focused on education, marital status, location, distance from the district headquarters, age, the education levels of close relatives, income, expenditure, and other demographic variables. We also collected data on women's earnings and the number of hours they allocated to the labor market and the household in order to estimate the earnings and hours-of-work equations for working women.

The analysis is carried out at two levels: apart from a statistical analysis of the data, we use two nonlinear models-a logistic probability (logit) model and a normal probability (probit) model-and a linear probability model (LPM) to carry out an econometric analysis of FLFP. To explain the qualitative nature of the dependent variable, we assign a value of 1 to participating women and 0 to nonparticipating women, where $Y$ is the column vector of explanatory variables and $X$ is the row vector of the corresponding regression parameters by $\alpha$. 
In order to examine the robustness of our results, we apply the following three models to study the correlates of FLFP decisions:

The LPM is given by

$$
Y_{i}=\alpha X_{i}+\varepsilon_{i}
$$

The probit model is given by

$$
Y_{i}=\int_{-\infty}^{\infty} f(z) d z+\varepsilon_{i}
$$

In the logit model, the probability of occurrence increases with $x$ but never moves beyond the range $0-1$ and there is a nonlinear relationship between the variables. The model assumes the following cumulative probability density function:

$$
P_{i}=\frac{1}{1+e^{\left(-\beta X_{t}\right)}}
$$

where $P$ denotes the likelihood that $i$ person will participate in the labor force, $e$ is the exponential value, $\alpha$ is the row vector of the parameters, and $X_{i}$ is the column vector of the variables.

From the logistic probability equation, we derive the following regression equation or logit model:

$$
\operatorname{Ln}\left[\frac{P_{i}}{1-P_{i}}\right]=Y_{i}=\alpha X_{i}+\varepsilon_{i}
$$

In order to estimate the earnings function for women, we use the statistical earnings function of Mincer and Polachek (1974) and augment it to include other factors that affect women's earnings:

$$
\operatorname{LNFEI}_{i}=\alpha_{0}+\sum_{j=1}^{k} \alpha_{K} X_{k i}+u_{i}
$$

where $\left(L N F E I_{i}=\ln W_{i}\right)$ is the natural log of the earnings of the ith individual, $X_{k i}$ represents the explanatory variables, and $u_{i}$ is a random disturbance term. 
Similarly, we estimate the hours-of-work equation using the OLS model in linear form:

$$
M H W_{i}=\beta_{0}+\sum_{j=1}^{k} \beta_{K} X_{k i}+u_{i}
$$

where $M H W_{i}$ denotes the hours of work per month, $u_{i}$ is a random error term, and $X_{k i}$ represents the explanatory variables.

\section{Model Specification and Selection of Variables}

In order to investigate the effect of different explanatory variables (Table 1) on FLFP, we estimate four models (all the variables are defined in Table 1):

The first model for FLFP is given below:

FLFP $_{\mathrm{i}}=\alpha+\beta_{1}$ AGEI $_{\mathrm{i}}+\beta_{2} \mathrm{AGEIII}_{\mathrm{i}}+\beta_{3} \mathrm{AGEIV}_{\mathrm{i}}+\beta_{4} \mathrm{AGEV}_{\mathrm{i}}+\beta_{5} \mathrm{FA}_{\mathrm{i}}+\beta_{6} \mathrm{BA}_{\mathrm{i}}+$ $\beta_{7} \mathrm{MST}_{\mathrm{i}}+\beta_{8} \mathrm{HE}_{\mathrm{i}}+\beta_{9} \mathrm{EDM}_{\mathrm{i}}+\beta_{10} \mathrm{EDF}_{\mathrm{i}}+\beta_{11} \mathrm{EDH}_{\mathrm{i}}+\beta_{12} \mathrm{MAS}_{\mathrm{i}}+\beta_{13} \mathrm{MRED}_{\mathrm{i}}+$ $\beta_{14} \mathrm{FSP}_{\mathrm{i}}+\beta_{15} \mathrm{LCN}_{\mathrm{i}}+\beta_{16} \mathrm{DSN}_{\mathrm{i}}+\beta_{17} \mathrm{NDP}_{\mathrm{i}}+\beta_{18} \mathrm{HEM}_{\mathrm{i}}+\beta_{19} \mathrm{HIN}_{\mathrm{i}}+\beta_{20} \mathrm{OEM}_{\mathrm{i}}+$ $\beta_{21} \mathrm{FEX}_{\mathrm{i}}+\beta_{22} \mathrm{ONH}_{\mathrm{i}}+\beta_{23} \mathrm{ONL}_{\mathrm{i}}+\beta_{24} \mathrm{LSK}_{\mathrm{i}}+\mathrm{\epsilon}_{\mathrm{i}}$

In the second model, we take women's age in completed years as the independent variable while the other variables remain the same as in model 1:

$\mathrm{FLFP}_{\mathrm{i}}=\alpha+\beta_{1} \mathrm{AGE}_{\mathrm{i}}+\beta_{2} \mathrm{FA}_{\mathrm{i}}+\beta_{3} \mathrm{BA}_{\mathrm{i}}+\beta_{4} \mathrm{MST}_{\mathrm{i}}+\beta_{5} \mathrm{HE}_{\mathrm{i}}+\beta_{6} \mathrm{EDM}_{\mathrm{i}}+\beta_{7} \mathrm{EDF}_{\mathrm{i}}+$ $\beta_{8} \mathrm{EDH}_{\mathrm{i}}+\beta_{9} \mathrm{MAS}_{\mathrm{i}}+\beta_{10} \mathrm{MRED}_{\mathrm{i}}+\beta_{11} \mathrm{FSP}_{\mathrm{i}}+\beta_{12} \mathrm{LCN}_{\mathrm{i}}+\beta_{13} \mathrm{DSN}_{\mathrm{i}}+\beta_{14} \mathrm{NDP}_{\mathrm{i}}+$ $\beta_{15} \mathrm{HEM}_{\mathrm{i}}+\beta_{16} \mathrm{HIN}_{\mathrm{i}}+\beta_{17} \mathrm{OEM}_{\mathrm{i}}+\beta_{18} \mathrm{FEX}_{\mathrm{i}}+\beta_{19} \mathrm{ONH}_{\mathrm{i}}+\beta_{20} \mathrm{ONL}+\beta_{21} \mathrm{LSK}_{\mathrm{i}}+\epsilon_{\mathrm{i}}$

The third model takes women's schooling in completed years as the independent variable while the other variables are the same as in model 1:

$\mathrm{FLFP}_{\mathrm{i}}=\alpha+\beta_{1} \mathrm{AGEI}_{\mathrm{i}}+\beta_{2} \mathrm{AGEIII}_{\mathrm{i}}+\beta_{3} \mathrm{AGEIV}_{\mathrm{i}}+\beta_{4} \mathrm{AGEV}_{\mathrm{i}}+\beta_{5} \mathrm{EDU}_{\mathrm{i}}+\beta_{6} \mathrm{EDM}_{\mathrm{i}}+$ $\beta_{7} \mathrm{EDF}_{\mathrm{i}}+\beta_{8} \mathrm{EDH}_{\mathrm{i}}+\beta_{9} \mathrm{MAS}_{\mathrm{i}}+\beta_{10} \mathrm{MRED}_{\mathrm{i}}+\beta_{11} \mathrm{FSP}_{\mathrm{i}}+\beta_{12} \mathrm{LCN}_{\mathrm{i}}+\beta_{13} \mathrm{DSN}_{\mathrm{i}}+$ $\beta_{14} \mathrm{NDP}_{\mathrm{i}}+\beta_{15} \mathrm{HEM}_{\mathrm{i}}+\beta_{16} \mathrm{HIN}_{\mathrm{i}}+\beta_{17} \mathrm{OEM}_{\mathrm{i}}+\beta_{18} \mathrm{FEX}_{\mathrm{i}}+\beta_{19} \mathrm{ONH}_{\mathrm{i}}+\beta_{20} \mathrm{ONL}_{\mathrm{i}}+$ $\beta_{21} \mathrm{LSK}_{\mathrm{i}}+\mathrm{E}_{\mathrm{i}}$

The fourth model includes women's age and schooling in completed years as explanatory variables while the other variables are the same as in model 1: 
$\mathrm{FLFP}_{\mathrm{i}}=\alpha+\beta_{1} \mathrm{AGE}_{\mathrm{i}}+\beta_{2} \mathrm{EDU}_{\mathrm{i}}+\beta_{3} \mathrm{EDM}_{\mathrm{i}}+\beta_{4} \mathrm{EDF}_{\mathrm{i}}+\beta_{5} \mathrm{EDH}_{\mathrm{i}}+\beta_{6} \mathrm{MAS}_{\mathrm{i}}+$ $\beta_{7} \mathrm{MRED}_{\mathrm{i}}+\beta_{8} \mathrm{FSP}_{\mathrm{i}}+\beta_{9} \mathrm{LCN}_{\mathrm{i}}+\beta_{10} \mathrm{DSN}_{\mathrm{i}}+\beta_{11} \mathrm{NDP}_{\mathrm{i}}+\beta_{12} \mathrm{HEM}_{\mathrm{i}}+\beta_{13} \mathrm{HIN}_{\mathrm{i}}+$ $\beta_{14} \mathrm{OEM}_{\mathrm{i}}+\beta_{15} \mathrm{FEX}_{\mathrm{i}}+\beta_{16} \mathrm{ONH}_{\mathrm{i}}+\beta_{17} \mathrm{ONL}_{\mathrm{i}}+\beta_{18} \mathrm{LSK}_{\mathrm{i}}+\epsilon_{\mathrm{i}}$

\subsection{Model Specification for Earnings Function}

We use three specifications to measure the FLFP earnings function. The first model includes completed years of schooling:

$\mathrm{LNFEI}_{\mathrm{i}}=\alpha+\beta_{1} \mathrm{EDU}_{\mathrm{i}}+\beta_{2} \mathrm{EXPR}_{\mathrm{i}}+\beta_{3} \mathrm{EXPR}_{\mathrm{i}}+\beta_{4} \mathrm{NCH}_{\mathrm{i}}+\beta_{5} \mathrm{TCHR}_{\mathrm{i}}+\beta_{6} \mathrm{LHW}_{\mathrm{i}}+$ $\beta_{7} \mathrm{EMB}_{\mathrm{i}}+\beta_{8} \mathrm{WRD}_{\mathrm{i}}+\beta_{9} \mathrm{COM}_{\mathrm{i}}+\mathrm{\epsilon}_{\mathrm{i}}$

The second model includes various levels of education and their interaction terms with experience:

LNFEI $_{\mathrm{i}}=\alpha+\beta_{1} \mathrm{FA}_{\mathrm{i}}+\beta_{2} \mathrm{BA}_{\mathrm{i}}+\beta_{3} \mathrm{MST}_{\mathrm{i}}+\beta_{4} \mathrm{HE}_{\mathrm{i}}+\beta_{5} \mathrm{FAEXP}_{\mathrm{i}}+\beta_{6} \mathrm{BAEXP}_{\mathrm{i}}+$ $\beta_{7}$ MSTEXP $_{\mathrm{i}}+\beta_{8}$ HEEXP $_{\mathrm{i}}+\beta_{9} \mathrm{NCH}_{\mathrm{i}}+\beta_{10}$ TCHR $_{\mathrm{i}}+\beta_{11} \mathrm{LHW}_{\mathrm{i}}+\beta_{12}$ EMB $_{\mathrm{i}}+$ $\beta_{13} \mathrm{WRD}_{\mathrm{i}}+\beta_{14} \mathrm{COM}_{\mathrm{i}}+\mathrm{\epsilon}_{\mathrm{i}}$

The third model introduces instrumental variables such as the spouse's level of education, location, and distance from the district headquarters for the years of schooling.

$\mathrm{LNFEI}_{\mathrm{i}}=\alpha+\beta_{1} \mathrm{EXPR}_{\mathrm{i}}+\beta_{2} \mathrm{EXPR}_{\mathrm{i}}+\beta_{3} \mathrm{EDH}_{\mathrm{i}}+\beta_{4} \mathrm{LCN}_{\mathrm{i}}+\beta_{5} \mathrm{DSN}_{\mathrm{i}}+\beta_{6} \mathrm{NCH}_{\mathrm{i}}+$ $\beta_{7} \mathrm{TCHR}_{\mathrm{i}}+\beta_{8} \mathrm{LHW}_{\mathrm{i}}+\beta_{9} \mathrm{EMB}_{\mathrm{i}}+\beta_{10} \mathrm{WRD}_{\mathrm{i}}+\beta_{11} \mathrm{COM}_{\mathrm{i}}+\mathrm{\epsilon}_{\mathrm{i}}$

\subsection{Hours-of-Work Equation}

The hours-of-work equation also helps determine the female labor supply function as given below:

$\mathrm{MHW}_{\mathrm{i}}=\alpha+\beta_{1} \mathrm{AGE}_{\mathrm{i}}+\beta_{2} \mathrm{AGE}_{\mathrm{i}}+\beta_{3} \mathrm{EDU}_{\mathrm{i}}+\beta_{4} \mathrm{DOC}_{\mathrm{i}}+\beta_{5} \mathrm{LHW}_{\mathrm{i}}+\beta_{6} \mathrm{EMB}_{\mathrm{i}}+$ $\beta_{7} \mathrm{WRD}_{\mathrm{i}}+\beta_{8} \mathrm{COM}_{\mathrm{i}}+\beta_{9} \mathrm{NDP}_{\mathrm{i}}+\beta_{10} \mathrm{HRH}_{\mathrm{i}}+\mathrm{e}_{\mathrm{i}}$

Table 1 defines the variables used in the above models. 
Table 1: Definition of variables and their relationships

\begin{tabular}{|c|c|c|}
\hline Variable & Description & $\begin{array}{l}\text { Hypothesized } \\
\text { relationship with } \\
\text { FLP }\end{array}$ \\
\hline FLFP & 1 if woman participates in the labor force, otherwise 0. & \\
\hline AGE & Woman's age in completed years & Positive \\
\hline AGE2 & Square of woman's age & Negative \\
\hline AGEI & 1 if woman is $15-24$ years old, otherwise 0 . & Negative/positive \\
\hline AGEII & 1 if woman is $25-34$ years old, otherwise 0 . & Positive \\
\hline AGEIII & 1 if woman is $35-44$ years old, otherwise 0 . & Positive \\
\hline AGEIV & 1 if woman is $45-54$ years old, otherwise 0 . & Positive \\
\hline AGEV & 1 if woman is $55-64$ years old, otherwise 0 . & Positive/negative \\
\hline EXPR & Work experience in years & Positive \\
\hline EXPR2 & Square of work experience & Negative \\
\hline EDU & Education in completed years & Positive \\
\hline MAT & 1 if woman has matriculated, otherwise 0. & Positive \\
\hline FA & 1 if woman has an FA, otherwise 0. & Positive \\
\hline BA & 1 if woman has a BA, otherwise 0 . & Positive \\
\hline MST & 1 if woman has an MA, otherwise 0. & Positive \\
\hline $\mathrm{HE}$ & 1 if woman has a post-MA qualification, otherwise 0 . & Positive \\
\hline EDM & Mother's years of schooling & Positive \\
\hline EDF & Father's years of schooling & Positive \\
\hline EDUH & Husband's years of schooling & Positive \\
\hline MAS & 1 if woman is married, otherwise 0. & Negative \\
\hline MRED & Interaction term (education $\times$ married woman) & Positive/negative \\
\hline FSP & 1 for a joint family system, otherwise 0 . & Positive \\
\hline LCN & 1 if woman lives in an urban area, otherwise 0. & Positive/negative \\
\hline DSN & Distance from district headquarter & Negative \\
\hline $\mathrm{NCH}$ & Number of dependent's children & Positive/negative \\
\hline NDP & Number of dependents (other than children) & Positive/negative \\
\hline HEM & 1 if husband is employed, otherwise 0 . & Positive \\
\hline $\mathrm{HIN}$ & Income of husband & Negative \\
\hline OEM & 1 if any other household member is employed, otherwise 0 . & Negative \\
\hline FEI & Woman's monthly income & Positive/negative \\
\hline FEX & Monthly family expenditures & Positive \\
\hline MHW & Hours worked per month & Positive \\
\hline $\mathrm{HRH}$ & Hours spent on household activities & Negative/positive \\
\hline $\mathrm{ONH}$ & 1 if woman owns a house, otherwise 0. & Negative/positive \\
\hline ONL & 1 if woman owns land, otherwise 0. & Negative/positive \\
\hline LSK & 1 if woman owns livestock, otherwise 0. & Negative/positive \\
\hline
\end{tabular}




\begin{tabular}{|c|c|c|}
\hline Variable & Description & $\begin{array}{l}\text { Hypothesized } \\
\text { relationship with } \\
\text { FLP }\end{array}$ \\
\hline TCHR & 1 if woman works as a teacher, otherwise 0. & Negative/positive \\
\hline DOC & 1 if woman works as a doctor, otherwise 0 . & Negative/positive \\
\hline LHW & 1 if woman works as a lady health worker, otherwise 0. & Negative/positive \\
\hline EMB & 1 if woman is engaged in embroidery work, otherwise 0. & Negative/positive \\
\hline WARD & 1 if woman works as a ward assistant, otherwise 0. & Negative/positive \\
\hline COM & 1 if woman works as a computer operator, otherwise 0. & Negative/positive \\
\hline
\end{tabular}

Source: Authors' calculations.

\section{Results and Discussion}

This section presents our empirical analysis.

\subsection{Descriptive Analysis}

The mean and standard deviation of all the variables are reported in Table 2. The average age of the respondents is 31.13 years with a standard deviation of about 8.51 . On average, $0.206,0.476,0.226$, and 0.063 working women are in the age groups AGEI (15-24), AGEII (25-34), AGEIII (35-44), and AGEIV (45-55), respectively. Only 0.026 working women are in the oldest age group AGEV (55-64). The average level of education is 13.2 years of schooling with a variation of 299 percent. On average, $0.25,0.19,0.22,0.26$, and 0.07 women have matriculated and earned an intermediate (FA), graduate (BA), Master's (MA), and postMaster's degree, respectively. On average, $0.53,0.46$, and 0.58 women are married, live in a joint family, and live in an urban area, respectively. 
Table 2: Descriptive statistics for selected variables

\begin{tabular}{|c|c|c|c|c|}
\hline Variable & Mean & SD & Skewness & Kurtosis \\
\hline AGE & 31.1333 & 8.51139 & 0.953 & 0.915 \\
\hline AGEI & 0.2067 & 0.40559 & 1.456 & 0.121 \\
\hline AGEII & 0.4767 & 0.50029 & 0.094 & -2.005 \\
\hline AGEIII & 0.2267 & 0.41937 & 1.312 & -0.280 \\
\hline AGEIV & 0.0633 & 0.24397 & 3.604 & 11.061 \\
\hline AGEV & 0.0267 & 0.16138 & 5.906 & 33.096 \\
\hline EDU & 13.2033 & 2.99196 & -0.325 & -0.581 \\
\hline MAT & 0.2533 & 0.43565 & 1.140 & -0.705 \\
\hline FA & 0.1900 & 0.39296 & 1.588 & 0.526 \\
\hline BA & 0.2233 & 0.41718 & 1.335 & -0.219 \\
\hline MST & 0.2633 & 0.44118 & 1.080 & -0.839 \\
\hline $\mathrm{HE}$ & 0.0700 & 0.25557 & 3.388 & 9.539 \\
\hline EDM & 4.9833 & 5.20192 & 0.462 & -1.205 \\
\hline EDF & 8.9533 & 5.61810 & -0.431 & -1.054 \\
\hline $\mathrm{EDH}$ & 6.7700 & 6.86787 & 0.193 & -1.695 \\
\hline FSP & 0.4600 & 0.49923 & 0.161 & -1.987 \\
\hline MAS & 0.5333 & 0.49972 & -0.134 & -1.995 \\
\hline $\mathrm{LCN}$ & 0.5800 & 0.49438 & -0.326 & -1.907 \\
\hline DSN & 35.3033 & 29.30119 & 0.717 & -0.760 \\
\hline $\mathrm{NCH}$ & 1.2233 & 1.60271 & 1.074 & 0.099 \\
\hline NDP & 1.8567 & 1.60563 & 0.348 & -0.959 \\
\hline HEM & 0.4667 & 0.49972 & 0.134 & -1.995 \\
\hline HIN & $14,810.0000$ & $20,920.63119$ & 1.602 & 2.390 \\
\hline OEM & 0.5600 & 0.49722 & -0.243 & -1.954 \\
\hline FIN & $42,731.1667$ & $25,082.01871$ & 1.535 & 4.765 \\
\hline FEX & $38,044.0000$ & $19,808.24962$ & 1.223 & 3.049 \\
\hline $\mathrm{ONH}$ & 0.1100 & 0.31341 & 2.505 & 4.306 \\
\hline ONL & 0.4200 & 0.49438 & 0.326 & -1.907 \\
\hline LSK & 0.2500 & 0.43374 & 1.161 & -0.658 \\
\hline
\end{tabular}

Source: Authors' field survey calculations.

\subsection{Econometric Analysis}

Table 3 shows that there is not much difference in the qualitative nature of results across the three probability models of LFP. The most important factors affecting women's decision to participate in the labor force are age, the level of education, marital status, family structure, 
location, distance from the district headquarters, the spouse's income, family expenditures, and ownership of assets.

The intercept term indicates the average effect of all other omitted variables on the dependent variable. The value of $\mathrm{R}^{2}$ in the LPM and of McFadden's $\mathrm{R}^{2}$ in the probit and logit regressions should not be taken as reflecting poorly on the quality of our results. A low $\mathrm{R}^{2}$ is typical of crosssectional studies, especially when the number of observations is in the hundreds. Inevitably, numerous unknown factors influence the dependent variable no matter how carefully one has selected the potential explanatory variables.

In model 1 (Table 3), the value of $\mathrm{R}^{2}$ and McFadden's $\mathrm{R}^{2}$ is 0.40 and 0.37 , which shows that the explanatory variables explain 40 and 37 percent of the variation in FLFP, respectively. Women in the age group AGEI (1524) are less likely to participate in the labor force compared to those in AGEII (25-34). This is explained by social constraints and the lack of experience, skills, and training as well as by the fact that many younger women may still be completing their education or maybe busy caring for young children.

The coefficients of AGEIII (35-44 years) and AGEIV (45-54 years) are positive and significant because women may have school- or collegegoing children, giving them more time to work outside the home. In the LPM, FLFP increases by 27.2 percent and 30.5 percent with each additional woman in the age groups AGEIII and AGEIV, respectively. The probability of FLFP increases by 1.03 and 1.32 units in the probit model and by 1.80 and 2.34 units in the logit model for the age groups AGEIII and AGEIV, respectively. The coefficient of AGEV (55-64 years) is negative and insignificant because older women are likely to be in poorer health and thus less productive. Our results concerning the age of the female labor force are similar to the findings of Naqvi and Shahnaz (2002) and Hafeez and Ahmad (2002).

Women's level of education is a key determinant of their decision to enter the labor market. Our results show that the relationship between FLFP and different levels of education is positive and significant: the higher the level of education, the higher is the likelihood of FLFP. The LPM indicates that women with a Master's degree or beyond are 48.8 and 70.2 percentage points more likely to participate in the labor force compared to those with a matriculation certificate. The probability of FLFP increases by 1.71 and 2.62 units in the probit model and by 2.94 and 4.70 units in the 
logit model with respect to women with a Master's degree or more. Clearly, higher levels of education enhance women's job opportunities outside the home and their capacity to generate an income. These results reflect Becker's (1965) theory of household production and time allocation. Higher levels of education increase the opportunity cost of producing nonmarket output as well as the probability of participating in incomegenerating activities outside the home. Ahmad and Hafeez (2007) and Kozel and Alderman (1990) present similar findings.

In examining the impact of the level of education among women's close relatives (mother, father, and spouse), we find that the coefficient of the mother's education is insignificant in all three models. This implies that their mothers' level of education does not affect women's decision to participate in the labor force. The coefficients of the father's level of education and the husband's level of education are, however, significant at 1 percent. Each additional year of education in the father's case decreases the probability of FLFP by 0.07 in the probit model and by 0.13 in the logit model. This is presumably because household income rises in tandem with the father's level of education with a corresponding decrease in the participation rate of educated women. In rural households in particular, fathers may be more reluctant to allow their daughters to work. Women's participation in the labor force increases with their spouses' level of education, possibly because of fewer social constraints and women's desire to provide their children with a better life. Our results with respect to the spouse's level of education are similar to those of Faridi, Malik, and Basit (2009).

Marital status is another key variable influencing women's decision to participate in the labor market. We find there is a positive and significant relationship between married women and FLFP. Faridi, Sharif et al. (2009) and Ejaz (2007) present similar findings.

Family structure is an important determinant of FLFP. Although the LPM does not yield a significant regression coefficient, both the probit and logit models indicate that the coefficient is significant. Family structure has a positive and significant effect on FLFP. The probability of FLFP increases by 0.41 (probit model) and 0.66 (logit model) with each additional woman in a joint family. This may be because it becomes possible to share the burden of domestic responsibilities or for one woman to substitute for another in this context. Faridi, Sharif et al. (2009) and Naqvi and Shahnaz (2002) corroborate this finding. 
The effect of location and distance from the district headquarters on FLFP is negative and significant at the 5 percent level. Rural women are more likely to participate in the labor market than urban women because rural incomes are generally lower than urban incomes. Khan and Khan (2009) present a similar finding. Additionally, the LPM shows that a onekilometer increase in the distance from the district headquarters decreases the probability of FLFP by 0.3 percentage points because of the associated increase in transport costs. Faridi, Sharif et al. (2009) corroborate this result.

The number of dependents has a positive but insignificant effect on FLFP: women living in households with a large number of dependents are likely to face greater economic pressure, compelling them to enter the labor market. Ahmad and Hafeez (2007) support this finding. The coefficient of the employment status of the husband and other working members of the household is insignificant. An increase in the husband's income will likely reduce the need for his wife to participate in the labor force. The presence of other working members of the household has a similar effect. Ahmad and Hafeez (2007) present similar results.

The coefficient of family expenditure is positive and insignificant in the LPM but significant in the probit and logit models. An increase in family expenditures will increase the likelihood of FLFP, given the need for women to participate in the labor force for cash remuneration. Ownership of assets (house, land, and livestock) has a negative and significant relationship with FLFP. The coefficients of ONH and ONL are significant at the 1 percent level in all three models, while the coefficient of LSK is insignificant. Ownership of assets increases household wealth and financial stability, making it less likely for women to seek employment. Ahmad and Hafeez (2007) and Faridi, Sharif et al. (2009) put forward similar findings.

Table 3: Estimated probability model 1 for FLFP

\begin{tabular}{lccc}
\hline Explanatory variable & LPM & Probit model & Logit model \\
\hline Constant & $0.546^{* * *}$ & 0.297 & 0.558 \\
& $(3.061)$ & $(0.437)$ & $(0.484)$ \\
\hline Age group (AGEII [25-34 years] is reference category) & \\
AGEI & -0.058 & -0.311 & -0.528 \\
& $(-0.812)$ & $(-1.196)$ & $(-1.204)$ \\
AGEIII & $0.272^{* * *}$ & $1.037^{* * *}$ & $1.807^{* * *}$ \\
& $(3.854)$ & $(3.479)$ & $(3.453)$ \\
AGEIV & $0.309^{* * *}$ & $1.321^{* *}$ & $2.346^{* * *}$ \\
& $(2.458)$ & $(2.386)$ & $(2.327)$ \\
\hline
\end{tabular}




\begin{tabular}{|c|c|c|c|}
\hline Explanatory variable & LPM & Probit model & Logit model \\
\hline AGEV & $\begin{array}{c}-0.168 \\
(-0.928)\end{array}$ & $\begin{array}{c}-0.984 \\
(-1.313)\end{array}$ & $\begin{array}{l}-1.583 \\
(-1.234)\end{array}$ \\
\hline \multicolumn{4}{|c|}{ Education level (matriculation is reference category) } \\
\hline FA & $\begin{array}{l}0.233^{* * *} \\
(2.902)\end{array}$ & $\begin{array}{l}0.971^{* * *} \\
(2.990)\end{array}$ & $\begin{array}{l}1.630^{* * *} \\
(2.903)\end{array}$ \\
\hline BA & $\begin{array}{l}0.302^{* * *} \\
(3.495)\end{array}$ & $\begin{array}{l}1.163^{* * *} \\
(3.331)\end{array}$ & $\begin{array}{l}1.991^{* * *} \\
(3.301)\end{array}$ \\
\hline MST & $\begin{array}{l}0.484^{* * *} \\
(4.348)\end{array}$ & $\begin{array}{l}1.712^{* * *} \\
(3.917)\end{array}$ & $\begin{array}{l}2.942^{* * *} \\
(3.822)\end{array}$ \\
\hline $\mathrm{HE}$ & $\begin{array}{l}0.702^{* * *} \\
(4.371)\end{array}$ & $\begin{array}{l}2.625^{* * * *} \\
(3.988)\end{array}$ & $\begin{array}{l}4.707^{* * * *} \\
(3.962)\end{array}$ \\
\hline \multicolumn{4}{|c|}{ Close relatives' education } \\
\hline EDM & $\begin{array}{c}0.004 \\
(0.657)\end{array}$ & $\begin{array}{c}0.020 \\
(0.744)\end{array}$ & $\begin{array}{c}0.038 \\
(0.822)\end{array}$ \\
\hline EDF & $\begin{array}{l}-0.019^{* * * *} \\
(-3.062)\end{array}$ & $\begin{array}{l}-0.074^{* * *} \\
(-3.018)\end{array}$ & $\begin{array}{l}-0.133^{* * *} \\
(-3.060)\end{array}$ \\
\hline $\mathrm{EDH}$ & $\begin{array}{l}0.033^{* * *} \\
(3.043)\end{array}$ & $\begin{array}{l}0.137^{* *} \\
(3.229)\end{array}$ & $\begin{array}{l}0.258^{* * *} \\
(3.341)\end{array}$ \\
\hline \multicolumn{4}{|c|}{ Other socioeconomic and demographic variables } \\
\hline MAS & $\begin{array}{l}0.811^{* * *} \\
(2.973)\end{array}$ & $\begin{array}{l}2.935^{* *} \\
(2.576)\end{array}$ & $\begin{array}{l}4.853^{* *} \\
(2.352)\end{array}$ \\
\hline MRED & $\begin{array}{l}-0.063^{* * *} \\
(-3.415)\end{array}$ & $\begin{array}{l}-0.220^{* * *} \\
(-2.883)\end{array}$ & $\begin{array}{l}-0.383^{* * *} \\
(-2.788)\end{array}$ \\
\hline FSP & $\begin{array}{c}0.090 \\
(1.449)\end{array}$ & $\begin{array}{c}0.418^{*} \\
(1.761)\end{array}$ & $\begin{array}{c}0.668^{*} \\
(1.640)\end{array}$ \\
\hline LCN & $\begin{array}{l}-0.178 \\
(-1.499)\end{array}$ & $\begin{array}{l}-0.862^{*} \\
(-1.774)\end{array}$ & $\begin{array}{l}-1.486^{*} \\
(-1.764)\end{array}$ \\
\hline DSN & $\begin{array}{l}-0.003^{*} \\
(-1.849)\end{array}$ & $\begin{array}{l}-0.016^{* *} \\
(-2.223)\end{array}$ & $\begin{array}{l}-0.028^{* *} \\
(-2.173)\end{array}$ \\
\hline NDP & $\begin{array}{c}0.032 \\
(1.289)\end{array}$ & $\begin{array}{c}0.093 \\
(1.023)\end{array}$ & $\begin{array}{c}0.182 \\
(1.167)\end{array}$ \\
\hline HEM & $\begin{array}{l}-0.165 \\
(-1.302)\end{array}$ & $\begin{array}{l}-0.785 \\
(-1.593)\end{array}$ & $\begin{array}{l}-1.168 \\
(-1.134)\end{array}$ \\
\hline HIN & $\begin{array}{l}-9.47 \mathrm{E}-05^{* * *} \\
(-4.799)\end{array}$ & $\begin{array}{l}-4.07 \mathrm{E}-05^{\text {***}} \\
(-4.705)\end{array}$ & $\begin{array}{l}-7.74 \mathrm{E}-05^{* * *} \\
(-4.247)\end{array}$ \\
\hline OEM & $\begin{array}{l}-0.048 \\
(-0.597)\end{array}$ & $\begin{array}{c}-0.143 \\
(-0.495)\end{array}$ & $\begin{array}{c}-0.248 \\
(-0.478)\end{array}$ \\
\hline FEX & $\begin{array}{l}2.37 \mathrm{E}-05 \\
(1.399)\end{array}$ & $\begin{array}{l}1.23 \mathrm{E}-05^{* *} \\
(1.984)\end{array}$ & $\begin{array}{l}1.98 \mathrm{E}-05^{*} \\
(1.765)\end{array}$ \\
\hline
\end{tabular}




\begin{tabular}{|c|c|c|c|}
\hline Explanatory variable & LPM & Probit model & Logit model \\
\hline $\mathrm{ONH}$ & $\begin{array}{l}-0.277^{* * *} \\
(-3.093)\end{array}$ & $\begin{array}{l}-1.231^{* * *} \\
(-3.152)\end{array}$ & $\begin{array}{l}-2.112^{* * *} \\
(-3.048)\end{array}$ \\
\hline ONL & $\begin{array}{l}-0.249^{* * * *} \\
(-4.681)\end{array}$ & $\begin{array}{l}-0.899^{* * *} \\
(-4.358)\end{array}$ & $\begin{array}{l}-1.548^{* * *} \\
(-4.322)\end{array}$ \\
\hline LSK & $\begin{array}{c}-0.101 \\
(-1.429)\end{array}$ & $\begin{array}{c}-0.394 \\
(-1.407)\end{array}$ & $\begin{array}{c}-0.664 \\
(-1.366)\end{array}$ \\
\hline Sample size & 300 & 300 & 300 \\
\hline $\mathrm{R}^{2}$ & 0.40 & - & - \\
\hline Adjusted $\mathrm{R}^{2}$ & 0.35 & - & - \\
\hline McFadden's R ${ }^{2}$ & - & 0.37 & 0.37 \\
\hline
\end{tabular}

Note: $z$-statistics are given in parentheses; ${ }^{* * *},{ }^{* *}$, and ${ }^{*}$ denote statistical significance at 1 , 5 , and 10 percent, respectively.

Source: Authors' calculations.

Model 2 (Table 4) includes women's age in completed years instead of different age groups; all other explanatory variables are the same as in model 1. The coefficient of AGE is positive but insignificant. The effects of all the variables are the same as in model 1 with some exceptions: the coefficient of FEX (family expenditure) is positive but insignificant in the logit model, and the coefficient of LSK (ownership of livestock) is negative and significant at 5 percent in the probit and logit models but insignificant in the LPM.

Table 4: Estimated probability model 2 for FLFP

\begin{tabular}{lccc}
\hline Explanatory variable & LPM & Probit model & Logit model \\
\hline Constant & $0.538^{* *}$ & 0.231 & 0.429 \\
& $(2.316)$ & $(0.285)$ & $(0.306)$ \\
\hline Age in completed years & & & \\
AGE & 0.006 & 0.023 & 0.038 \\
\multicolumn{1}{l}{$(1.281)$} & $(1.419)$ & $(1.376)$ \\
\hline Education level (matriculation is reference category) & \\
FA & $0.237^{* * *}$ & $0.901^{* * *}$ & $1.485^{* * *}$ \\
& $(2.887)$ & $(2.928)$ & $(2.828)$ \\
BA & $0.302^{* * *}$ & $1.113^{* * *}$ & $1.839^{* * *}$ \\
& $(3.458)$ & $(3.382)$ & $(3.315)$ \\
MST & $0.493^{* * *}$ & $1.725^{* * *}$ & $2.915^{* * *}$ \\
& $(4.594)$ & $(4.237)$ & $(4.120)$ \\
\hline
\end{tabular}




\begin{tabular}{|c|c|c|c|}
\hline Explanatory variable & LPM & Probit model & Logit model \\
\hline $\mathrm{HE}$ & $\begin{array}{l}0.709^{* * *} \\
(4.455)\end{array}$ & $\begin{array}{l}2.557^{* * *} \\
(4.111)\end{array}$ & $\begin{array}{l}4.378^{* * *} \\
(4.045)\end{array}$ \\
\hline \multicolumn{4}{|c|}{ Close relatives' education } \\
\hline EDM & $\begin{array}{c}0.005 \\
(0.649)\end{array}$ & $\begin{array}{c}0.022 \\
(0.893)\end{array}$ & $\begin{array}{c}0.038 \\
(0.850)\end{array}$ \\
\hline EDF & $\begin{array}{l}-0.019^{* * *} \\
(-3.016)\end{array}$ & $\begin{array}{l}-0.069^{* * *} \\
(-2.978)\end{array}$ & $\begin{array}{l}-0.122^{* * *} \\
(-2.971)\end{array}$ \\
\hline $\mathrm{EDH}$ & $\begin{array}{l}0.031^{* * *} \\
(2.798)\end{array}$ & $\begin{array}{l}0.102^{* * *} \\
(2.661)\end{array}$ & $\begin{array}{l}0.188^{* * *} \\
(2.757)\end{array}$ \\
\hline \multicolumn{4}{|c|}{ Other socioeconomic and demographic variables } \\
\hline MAS & $\begin{array}{l}0.971^{* * *} \\
(3.237)\end{array}$ & $\begin{array}{l}3.216^{* * *} \\
(3.035)\end{array}$ & $\begin{array}{l}5.228^{* * *} \\
(2.855)\end{array}$ \\
\hline MRED & $\begin{array}{l}-0.069^{* * *} \\
(-3.639)\end{array}$ & $\begin{array}{l}-0.236^{* * *} \\
(-3.289)\end{array}$ & $\begin{array}{l}-0.402^{* * *} \\
(-3.232)\end{array}$ \\
\hline FSP & $\begin{array}{c}0.085 \\
(1.324)\end{array}$ & $\begin{array}{r}0.366^{*} \\
(1.606)\end{array}$ & $\begin{array}{c}0.601 \\
(1.553)\end{array}$ \\
\hline LCN & $\begin{array}{l}-0.238^{* *} \\
(-1.958)\end{array}$ & $\begin{array}{l}-1.057^{*} \\
(-2.324)\end{array}$ & $\begin{array}{l}-1.720^{* *} \\
(-2.211)\end{array}$ \\
\hline DSN & $\begin{array}{l}-0.004^{* *} \\
(-2.365)\end{array}$ & $\begin{array}{l}-0.020^{* * *} \\
(-2.798)\end{array}$ & $\begin{array}{l}-0.032^{* * *} \\
(-2.663)\end{array}$ \\
\hline $\mathrm{NDP}$ & $\begin{array}{c}0.030 \\
(1.153)\end{array}$ & $\begin{array}{c}0.085 \\
(0.957)\end{array}$ & $\begin{array}{c}0.163 \\
(1.084)\end{array}$ \\
\hline HEM & $\begin{array}{c}-0.154 \\
(-1.186)\end{array}$ & $\begin{array}{c}-0.499 \\
(-1.140)\end{array}$ & $\begin{array}{c}-0.670 \\
(-0.771)\end{array}$ \\
\hline HIN & $\begin{array}{l}-8.98 \mathrm{E}-05^{* * *} \\
(-4.432)\end{array}$ & $\begin{array}{l}-3.41 \mathrm{E}-05^{* * *} \\
(-4.268)\end{array}$ & $\begin{array}{l}-6.28 \mathrm{E}-05^{* * *} \\
(-3.938)\end{array}$ \\
\hline OEM & $\begin{array}{c}-0.116 \\
(-1.428)\end{array}$ & $\begin{array}{c}-0.382 \\
(-1.403)\end{array}$ & $\begin{array}{l}-0.691 \\
(-1.419)\end{array}$ \\
\hline FEX & $\begin{array}{l}2.44 \mathrm{E}-05 \\
(1.423)\end{array}$ & $\begin{array}{l}9.29 \mathrm{E}-05^{*} \\
(1.621)\end{array}$ & $\begin{array}{l}1.45 \mathrm{E}-05 \\
(1.435)\end{array}$ \\
\hline $\mathrm{ONH}$ & $\begin{array}{l}-0.290^{* * *} \\
(-3.174)\end{array}$ & $\begin{array}{l}-1.152^{* * *} \\
(-3.174)\end{array}$ & $\begin{array}{l}-1.886^{* * *} \\
(-2.962)\end{array}$ \\
\hline ONL & $\begin{array}{l}-0.256^{* * *} \\
(-4.647)\end{array}$ & $\begin{array}{l}-0.867^{* * *} \\
(-4.457)\end{array}$ & $\begin{array}{l}-1.454^{* * *} \\
(-4.391)\end{array}$ \\
\hline LSK & $\begin{array}{c}-0.112 \\
(-1.530)\end{array}$ & $\begin{array}{l}-0.444^{*} \\
(-1.663)\end{array}$ & $\begin{array}{c}-0.753^{*} \\
(-1.650)\end{array}$ \\
\hline
\end{tabular}




\begin{tabular}{lccc}
\hline Explanatory variable & LPM & Probit model & Logit model \\
\hline Sample size & 300 & 300 & 300 \\
$\mathrm{R}^{2}$ & 0.35 & - & - \\
Adjusted R ${ }^{2}$ & 0.30 & - & - \\
McFadden's R & - & 0.31 & 0.31 \\
\hline
\end{tabular}

Note: $\mathrm{z}$-statistics are given in parentheses; ${ }^{* * *}, * *$, and ${ }^{*}$ denote statistical significance at 1 , 5 , and 10 percent, respectively.

Source: Authors' calculations.

Model 3 (Table 5) includes women's education in completed years instead of different levels of education. The coefficient of education is positive and significant at 1 percent and all the variables have the same impact on FLFP as in model 1. However, the coefficient of HEM (husband's employment status) is significant in the probit model, while the coefficient of FEX (family expenditure) is significant in the LPM.

Table 5: Estimated probability model 3 for FLFP

\begin{tabular}{lccc}
\hline Explanatory variable & LPM & Probit model & Logit model \\
\hline Constant & -0.050 & $-2.029^{* *}$ & -3.407 \\
& $(-0.203)$ & $(-2.089)$ & $(-2.080)$ \\
\hline Age group (AGEII [25-34 years] is reference category) & \\
AGEI & -0.083 & -0.366 & -0.639 \\
& $(-1.229)$ & $(-1.472)$ & $(-1.513)$ \\
AGEIII & $0.278^{* * *}$ & $1.063^{* * *}$ & $1.828^{* * *}$ \\
& $(3.937)$ & $(3.560)$ & $(3.525)$ \\
AGEIV & $0.284^{* *}$ & $1.259^{* *}$ & $2.241^{* *}$ \\
& $(2.290)$ & $(2.294)$ & $(2.274)$ \\
AGEV & -0.215 & -1.083 & -1.744 \\
& $(-1.205)$ & $(-1.459)$ & $(-1.382)$ \\
\hline Education in completed years & & & \\
EDU & $0.067^{* * *}$ & $2.262^{* * *}$ & $0.449^{* * *}$ \\
& $(4.650)$ & $(4.262)$ & $(4.183)$ \\
\hline Close relatives' education & & & \\
EDM & 0.005 & 0.023 & 0.044 \\
& $(0.720)$ & $(0.876)$ & $(0.950)$ \\
EDF & $-0.019^{*}$ & $-0.077^{* * *}$ & $-0.138^{* * *}$ \\
& $(-3.080)$ & $(-3.126)$ & $(-3.149)$ \\
EDH & $0.034^{*}$ & $0.147^{* * *}$ & $0.268^{* * *}$ \\
& $(3.215)$ & $(3.460)$ & $(3.477)$ \\
\hline
\end{tabular}

Other socioeconomic and demographic variables 


\begin{tabular}{|c|c|c|c|}
\hline Explanatory variable & LPM & Probit model & Logit model \\
\hline MAS & $\begin{array}{l}0.788^{* * *} \\
(2.957)\end{array}$ & $\begin{array}{l}3.044^{* * *} \\
(2.684)\end{array}$ & $\begin{array}{l}4.911^{* *} \\
(2.444)\end{array}$ \\
\hline MRED & $\begin{array}{l}-0.062^{* * *} \\
(-3.427)\end{array}$ & $\begin{array}{l}-0.232^{* * *} \\
(-3.055)\end{array}$ & $\begin{array}{l}-0.394^{* * *} \\
(-2.951)\end{array}$ \\
\hline FSP & $\begin{array}{c}0.095 \\
(1.541)\end{array}$ & $\begin{array}{l}0.428^{*} \\
(1.830)\end{array}$ & $\begin{array}{l}0.708^{*} \\
(1.752)\end{array}$ \\
\hline LCN & $\begin{array}{c}-0.184 \\
(-1.566)\end{array}$ & $\begin{array}{l}-0.881^{*} \\
(-1.837)\end{array}$ & $\begin{array}{l}-1.515^{*} \\
(-1.830)\end{array}$ \\
\hline DSN & $\begin{array}{l}-0.004^{* * *} \\
(-1.972)\end{array}$ & $\begin{array}{l}-0.017^{* *} \\
(-2.348)\end{array}$ & $\begin{array}{l}-0.030^{* *} \\
(-2.287)\end{array}$ \\
\hline NDP & $\begin{array}{c}0.029 \\
(1.163)\end{array}$ & $\begin{array}{c}0.089 \\
(0.999)\end{array}$ & $\begin{array}{c}0.167 \\
(1.067)\end{array}$ \\
\hline HEM & $\begin{array}{c}-0.176 \\
(-1.394)\end{array}$ & $\begin{array}{r}-0.883^{*} \\
(-1.786)\end{array}$ & $\begin{array}{c}-1.130 \\
(-1.292)\end{array}$ \\
\hline HIN & $\begin{array}{l}-9.76 \mathrm{E}-05^{* * *} \\
(-5.026)\end{array}$ & $\begin{array}{l}-4.07 \mathrm{E}-05^{* * *} \\
(-4.748)\end{array}$ & $\begin{array}{l}-7.60 \mathrm{E}-05^{* * *} \\
(-4.258)\end{array}$ \\
\hline OEM & $\begin{array}{c}-0.039 \\
(-0.489)\end{array}$ & $\begin{array}{c}-0.136 \\
(-0.478)\end{array}$ & $\begin{array}{c}-0.250 \\
(-0.483)\end{array}$ \\
\hline FEX & $\begin{array}{l}2.69 \mathrm{E}-05^{*} \\
(1.631)\end{array}$ & $\begin{array}{l}1.18 \mathrm{E}-05^{*} \\
(1.944)\end{array}$ & $\begin{array}{l}1.92 \mathrm{E}-05^{*} \\
(1.728)\end{array}$ \\
\hline $\mathrm{ONH}$ & $\begin{array}{l}-0.271^{* * *} \\
(-3.051)\end{array}$ & $\begin{array}{l}-1.178^{* * *} \\
(-3.142)\end{array}$ & $\begin{array}{l}-1.957^{* * *} \\
(-3.017)\end{array}$ \\
\hline ONL & $\begin{array}{l}-0.252^{* * *} \\
(-4.774)\end{array}$ & $\begin{array}{l}-0.893^{* * *} \\
(-4.356)\end{array}$ & $\begin{array}{l}-1.539^{* * *} \\
(-4.323)\end{array}$ \\
\hline LSK & $\begin{array}{c}-0.083 \\
(-1.178)\end{array}$ & $\begin{array}{c}-0.349 \\
(-1.240)\end{array}$ & $\begin{array}{c}-0.593 \\
(-1.214)\end{array}$ \\
\hline Sample size & 300 & 300 & 300 \\
\hline $\mathrm{R}^{2}$ & 0.40 & - & - \\
\hline Adjusted $\mathrm{R}^{2}$ & 0.35 & - & - \\
\hline McFadden's R ${ }^{2}$ & - & 0.37 & 0.37 \\
\hline
\end{tabular}

Note: $z$-statistics are given in parentheses; ${ }^{* * *},{ }^{* *}$, and ${ }^{*}$ denote statistical significance at 1 , 5 , and 10 percent, respectively.

Source: Authors' calculations.

Finally, model 4 (Table 6) includes both age and education in completed years. The coefficient of AGE is positive and insignificant while the coefficient of EDU is positive and significant. The effects of all the variables are the same as in model 1 , but the coefficient of location is significant in the LPM. 
Table 6: Estimated probability model 4 for FLFP

\begin{tabular}{|c|c|c|c|}
\hline Explanatory variable & LPM & Probit model & Logit model \\
\hline Constant & $\begin{array}{c}-0.056 \\
(-0.196)\end{array}$ & $\begin{array}{l}-1.950 \\
(-1.893)\end{array}$ & $\begin{array}{l}-3.299 \\
(-1.867)\end{array}$ \\
\hline \multicolumn{4}{|l|}{ Age in completed years } \\
\hline AGE & $\begin{array}{c}0.006 \\
(1.342)\end{array}$ & $\begin{array}{c}0.022 \\
(1.387)\end{array}$ & $\begin{array}{c}0.039 \\
(1.395)\end{array}$ \\
\hline \multicolumn{4}{|c|}{ Education in completed years } \\
\hline EDU & $\begin{array}{l}0.066^{* * *} \\
(4.589)\end{array}$ & $\begin{array}{l}0.246^{* * *} \\
(4.242)\end{array}$ & $\begin{array}{l}0.411^{* * *} \\
(4.144)\end{array}$ \\
\hline \multicolumn{4}{|c|}{ Close relatives' education } \\
\hline EDM & $\begin{array}{c}0.005 \\
(0.774)\end{array}$ & $\begin{array}{c}0.026 \\
(1.067)\end{array}$ & $\begin{array}{c}0.044 \\
(1.014)\end{array}$ \\
\hline EDF & $\begin{array}{l}-0.019^{* * *} \\
(-3.026)\end{array}$ & $\begin{array}{l}-0.071^{* * *} \\
(-3.041)\end{array}$ & $\begin{array}{l}-0.123^{* * *} \\
(-3.016)\end{array}$ \\
\hline $\mathrm{EDH}$ & $\begin{array}{l}0.032^{* * *} \\
(2.916)\end{array}$ & $\begin{array}{l}0.108^{* * *} \\
(2.822)\end{array}$ & $\begin{array}{l}0.192^{* * *} \\
(2.831)\end{array}$ \\
\hline \multicolumn{4}{|c|}{ Other socioeconomic and demographic variables } \\
\hline MAS & $\begin{array}{l}0.852^{* * *} \\
(3.066)\end{array}$ & $\begin{array}{l}3.146^{* * *} \\
(2.964)\end{array}$ & $\begin{array}{l}5.024^{* * *} \\
(2.767)\end{array}$ \\
\hline MRED & $\begin{array}{l}-0.065^{* * * *} \\
(-3.468)\end{array}$ & $\begin{array}{l}-0.232^{* * *} \\
(-3.232)\end{array}$ & $\begin{array}{l}-0.389^{* * *} \\
(-3.177)\end{array}$ \\
\hline FSP & $\begin{array}{c}0.090 \\
(1.412)\end{array}$ & $\begin{array}{r}0.381^{*} \\
(1.691)\end{array}$ & $\begin{array}{r}0.642^{*} \\
(1.680)\end{array}$ \\
\hline $\mathrm{LCN}$ & $\begin{array}{l}-0.254^{* *} \\
(-2.107)\end{array}$ & $\begin{array}{l}-1.091^{* *} \\
(-2.436)\end{array}$ & $\begin{array}{l}-1.767^{* *} \\
(-2.310)\end{array}$ \\
\hline DSN & $\begin{array}{l}-0.005^{*} \\
(-2.530)\end{array}$ & $\begin{array}{l}-0.020^{* * *} \\
(-2.952)\end{array}$ & $\begin{array}{l}-0.033^{* * *} \\
(-2.807)\end{array}$ \\
\hline NDP & $\begin{array}{c}0.026 \\
(0.988)\end{array}$ & $\begin{array}{c}0.074 \\
(0.854)\end{array}$ & $\begin{array}{c}0.145 \\
(0.974)\end{array}$ \\
\hline HEM & $\begin{array}{l}-0.153 \\
(-1.181)\end{array}$ & $\begin{array}{l}-0.512 \\
(-1.183)\end{array}$ & $\begin{array}{l}-0.655 \\
(-0.772)\end{array}$ \\
\hline HIN & $\begin{array}{l}-9.21 \mathrm{E}-05^{* * *} \\
(-4.591)\end{array}$ & $\begin{array}{l}-3.42 \mathrm{E}-05^{* * *} \\
(-4.345)\end{array}$ & $\begin{array}{l}-6.20 \mathrm{E}-05^{* * *} \\
(-3.973)\end{array}$ \\
\hline OEM & $\begin{array}{l}-0.103 \\
(-1.283)\end{array}$ & $\begin{array}{l}-0.343 \\
(-1.284)\end{array}$ & $\begin{array}{l}-0.626 \\
(-1.293)\end{array}$ \\
\hline FEX & $\begin{array}{l}2.80 \mathrm{E}-05^{*} \\
(1.652)\end{array}$ & $\begin{array}{l}9.40 \mathrm{E}-05^{*} \\
(1.668)\end{array}$ & $\begin{array}{l}1.49 \mathrm{E}-05^{*} \\
(1.480)\end{array}$ \\
\hline $\mathrm{ONH}$ & $\begin{array}{l}-0.289^{* * *} \\
(-3.169)\end{array}$ & $\begin{array}{l}-1.099 * * * \\
(-3.163)\end{array}$ & $\begin{array}{l}-1.768^{* * *} \\
(-2.950)\end{array}$ \\
\hline
\end{tabular}




\begin{tabular}{lccc}
\hline Explanatory variable & LPM & Probit model & Logit model \\
\hline ONL & $-0.259^{* * *}$ & $-0.864^{* * *}$ & $-1.447^{* * *}$ \\
& $(-4.726)$ & $(-4.481)$ & $(-4.406)$ \\
LSK & -0.094 & -0.398 & -0.673 \\
& $(-1.289)$ & $(-1.491)$ & $(-1.478)$ \\
Sample size & 300 & 300 & 300 \\
R2 & 0.34 & - & - \\
Adjusted R2 & 0.30 & - & - \\
McFadden's R 2 & - & 0.31 & 0.31 \\
\hline
\end{tabular}

Note: $z$-statistics are given in parentheses; ${ }^{* * *},{ }^{* *}$, and ${ }^{*}$ denote statistical significance at 1 , 5 , and 10 percent, respectively.

Source: Authors' calculations.

\subsection{Estimates of Earnings Equation for Working Women}

Table 7 gives the results for the earnings function of FLFP. Most of the regression coefficients are highly significant at 1 percent. Model 5(a), which incorporates the completed years of education, shows that the explanatory variables account for 61 percent of the variation in women's earnings as shown by $\mathrm{R}^{2}$. The literature has already established that women's education is a key determinant of their earnings and plays a vital role in human capital formation. The coefficient of EDU is positive and significant at 1 percent. Each additional year of schooling increases women's earnings by 9.4 percent because it improves their skills and their scope for obtaining a better-paid job. Our results are similar to those of Mincer and Polachek (1974), Nasir (2002), Ahmad and Hafeez (2007), Chaudhry et al. (2010), and Faridi, Malik, and Ahmed (2010).

The coefficient of experience is positive and significant: each additional year of experience (and thus of productivity) increases women's earnings by 16 percent. The coefficient of experience-squared is significant and negative, which suggests that experience has a decreasing impact over time. This may be because women's earnings initially rise and then fall with age as described in the lifecycle theory. Our results are similar to those of Ahmad and Hafeez (2007).

The number of children has a negative impact on married women's earnings: as their childcare responsibilities increase, they are likely to have less time to work outside the home. Our results are similar to Chaudhry et al. (2010). Finally, women's earnings also depend on their profession. The LPM shows that teachers and computer operators earn more than doctors, while health workers, ward assistants (lower medical staff), and women 
engaged in embroidery work earn less than doctors. In the logit model, only teachers earn more than doctors.

Table 7: Log linear estimates of earnings function (model 5)

\begin{tabular}{|c|c|c|c|}
\hline & $5 a$ & $5 b$ & $5 c$ \\
\hline Variable & $\begin{array}{c}\text { Completed years } \\
\text { of education }\end{array}$ & $\begin{array}{c}\text { Various education } \\
\text { levels }\end{array}$ & $\begin{array}{c}\text { Instrumental } \\
\text { variable }\end{array}$ \\
\hline$C$ & $\begin{array}{l}7.331^{* * *} \\
(17.373)\end{array}$ & $\begin{array}{l}9.293^{* * * *} \\
(41.682)\end{array}$ & $\begin{array}{l}8.714^{* * *} \\
(28.338)\end{array}$ \\
\hline EDU & $\begin{array}{l}0.094^{* * *} \\
(3.917)\end{array}$ & - & - \\
\hline FA & - & $\begin{array}{l}-0.416^{*} \\
(-1.797)\end{array}$ & - \\
\hline BA & - & $\begin{array}{l}-0.692^{* * *} \\
(-3.129)\end{array}$ & - \\
\hline MST & - & $\begin{array}{c}-0.086 \\
(-0.340)\end{array}$ & - \\
\hline $\mathrm{HE}$ & - & $\begin{array}{c}0.385 \\
(1.292)\end{array}$ & - \\
\hline FAEXP & - & $\begin{array}{l}0.056^{* * *} \\
(3.189)\end{array}$ & - \\
\hline BAEXP & - & $\begin{array}{l}0.066^{* * *} \\
(4.201)\end{array}$ & - \\
\hline MSTEXP & - & $\begin{array}{l}0.075^{* * *} \\
(3.672)\end{array}$ & - \\
\hline HEEXP & - & $\begin{array}{c}0.036 \\
(1.357)\end{array}$ & - \\
\hline EXP & $\begin{array}{l}0.160^{* * *} \\
(5.406)\end{array}$ & - & $\begin{array}{l}0.112^{* * *} \\
(3.327)\end{array}$ \\
\hline EXP2 & $\begin{array}{l}-0.004^{* * * *} \\
(-3.174)\end{array}$ & - & $\begin{array}{l}-0.003^{* *} \\
(-2.017)\end{array}$ \\
\hline $\mathrm{EDH}$ & - & - & $\begin{array}{l}0.024^{* *} \\
(2.417)\end{array}$ \\
\hline $\mathrm{LCN}$ & - & - & $\begin{array}{c}0.119 \\
(0.546)\end{array}$ \\
\hline DSN & - & - & $\begin{array}{c}0.003 \\
(0.836)\end{array}$ \\
\hline $\mathrm{NCH}$ & $\begin{array}{l}-0.057 \\
(-1.511)\end{array}$ & $\begin{array}{c}-0.028 \\
(-0.749)\end{array}$ & $\begin{array}{l}-0.084^{*} \\
(-1.846)\end{array}$ \\
\hline TCHR & $\begin{array}{l}0.224^{*} \\
(1.649)\end{array}$ & $\begin{array}{c}0.223 \\
(1.528)\end{array}$ & $\begin{array}{r}0.237^{*} \\
(1.627)\end{array}$ \\
\hline
\end{tabular}




\begin{tabular}{lccc}
\hline Variable & $\mathbf{5 a}$ & $\mathbf{5 b}$ & $\mathbf{5} \mathbf{c}$ \\
\cline { 2 - 4 } & $\begin{array}{c}\text { Completed years } \\
\text { of education }\end{array}$ & $\begin{array}{c}\text { Various education } \\
\text { levels }\end{array}$ & $\begin{array}{c}\text { Instrumental } \\
\text { variable }\end{array}$ \\
\hline LHW & -0.136 & 0.025 & $-0.374^{*}$ \\
EMB & $(-0.743)$ & $(0.128)$ & $(-1.824)$ \\
& $-0.651^{* * *}$ & $-0.824^{* * *}$ & $-1.037^{* * *}$ \\
WRD & $(-3.402)$ & $(-4.134)$ & $(-5.868)$ \\
& -0.101 & -0.014 & -0.331 \\
COM & $(-0.472)$ & $(-0.062)$ & $(-1.540)$ \\
& 0.001 & 0.153 & -0.081 \\
Sample size & $(0.003)$ & $(0.767)$ & $(-0.430)$ \\
R $^{2}$ & 156 & 156 & 156 \\
Adjusted $R^{2}$ & 0.61 & 0.61 & 0.59 \\
F-statistic & 0.59 & 0.57 & 0.56 \\
\hline
\end{tabular}

Note: ${ }^{* *}, * *$, and $*$ denote statistical significance at 1,5 , and 10 percent, respectively. Source: Authors' calculations.

Model 5(b) takes into account various levels of education and shows that the explanatory variables account for 61 percent of the variation in wage earnings as shown by $\mathrm{R}^{2}$. Women with an FA, BA, or MA earn less than those with a higher qualification. Using the interaction term (education with experience), the results show that the level of education with experience increases earnings.

Model 5(c) uses an instrumental variable. The results show that the explanatory variables account for 59 percent of the variation in wage earnings as shown by $\mathrm{R}^{2}$. The coefficient of experience is positive while that of experience-squared is negative and insignificant. The coefficient of EDH (husband's education) is positive and significant, which implies that bettereducated men are likely to encourage their wives to work, thereby increasing the latter's earnings.

Location and distance have a positive and insignificant impact, respectively, on women's wage earnings. Urban women tend to earn more than rural women because the former are likely to have better-paid occupations. Every one-kilometer increase in the distance from the district headquarters causes hourly wage earnings to rise by 0.3 percent, but the coefficient is statistically insignificant; distance, therefore, has more or less no effect on women's earnings. Ahmad and Hafeez (2007) find a negative relationship between distance and women's earnings. 


\subsection{Estimates of Hours-of-Work Equation for Working Women}

The overall explanatory power of the $\mathrm{R}^{2}$ term is reasonably high: it explains 68 percent of the variation in the hours-of-work equation. Table 8 (model 6) shows that some of the regression coefficients are statistically significant. The coefficient of age is positive and significant, implying that, as women grow older, they work longer hours in order to earn more. Most women in our sample (about 91 percent) are younger than 45, explaining why the hours of work increase with age in our analysis. The coefficient of AGE2 is negative and significant, suggesting that older women, who are likely to be in poorer health, work shorter hours. These findings are similar to those of Ahmad and Hafeez (2007).

The level of education has little effect on women's working hours; the coefficient is positive but insignificant. Occupation, however, is an important variable in this case: a one-unit increase in the number of women who are doctors-as opposed to teachers-will increase the monthly hours of work by 52 . A one-unit increase in the number of women who are health workers, ward assistants, or computer operators or who engage in embroidery work will decrease the monthly hours of work by 19, 41,6 , and 3, respectively. Ward assistants work longer hours but earn less because their jobs are low-paid.

Finally, our results show that the number of dependents and hours spent on household activities are negatively and significantly related to women's working hours. Similar to Ahmad and Hafeez (2007), we find that, as the number of dependents increases, women are likely to spend longer engaged in household activities and less time on market activities, with a corresponding fall in the hours of work. 
Table 8: Estimates for hours-of-work equation for working women (model 6)

\begin{tabular}{lccc}
\hline Variable & Coefficient & SE & t-statistic \\
\hline C & $78.355^{* * *}$ & 39.070 & 2.006 \\
AGE & $5.439^{* * *}$ & 1.926 & 2.824 \\
AGE2 & $-0.061^{* * *}$ & 0.027 & -2.255 \\
EDU & 1.399 & 1.156 & 1.210 \\
DOC & $52.038^{* * *}$ & 8.611 & 6.043 \\
LHW & $-19.300^{* * *}$ & 7.447 & -2.592 \\
EMB & $-41.995^{* * *}$ & 7.926 & -5.299 \\
WRD & -6.448 & 9.390 & -0.687 \\
COM & -3.810 & 7.704 & -0.495 \\
NDP & $-5.644^{* * *}$ & 1.714 & -3.292 \\
HRH & $-0.128^{* * *}$ & 0.055 & -2.354 \\
\hline R & 0.68 & F-statistic $=30.84$ & \\
Adjusted R & & Prob. (F-statistic) $=0.000$ \\
Total observations & 0.66 & & \\
\hline
\end{tabular}

Note: ${ }^{* * *},{ }^{* *}$, and ${ }^{*}$ denote statistical significance at 1,5 , and 10 percent, respectively. Source: Authors' calculations.

\section{Conclusion and Suggestions}

The present study has analyzed the correlates of educated women's LFP and the impact of various social and economic factors on their decision to participate in the labor market. The analysis was conducted as a case study of women in Multan who had completed at least eight years of schooling. The empirical results suggest that numerous factors explain FLFP in the district.

We find that the coefficients of all levels of education are significant and have a positive impact on FLFP. The coefficients of AGEIII, AGEIV, the husband's level of education and income, marital status, family structure, and family expenditures have a positive and significant impact on FLFP, while the coefficients of the father's education, location, distance, husband's employment status and income, family expenditures, and ownership of assets significantly reduce FLFP. The effect of AGEI, AGEV, the mother's education, the number of dependents, the husband's employment status, and the presence of other working members of the household is insignificant. Women's earnings increase if they live in an urban area and are highly educated and experienced. The number of working hours also rises with age and education. 
Based on these conclusions, we suggest the following policy measures:

- Entry into the labor market requires more than basic schooling. Therefore, efforts should be to make higher education more easily available to women throughout Pakistan, especially in rural areas.

- Policies to organize the informal sector and establish more agriculture-based industries would benefit women with less than a year of schooling, giving them the opportunity to work in such industries for cash remuneration.

- The government should initiate rural development programs that focus on creating more employment opportunities for educated women living in rural areas.

- The government should also ensure the provision of childcare resources such as childcare centers and primary schools to support and encourage educated mothers to participate in economic activities.

- Given that the rate of FLFP appears to initially increase with age and then decrease, older educated women could be encouraged to participate by providing benefits such as social security, annual increments, and pensions. 


\section{References}

Afzal, A., \& Bibi, A. (2012). Determinants of married women labor force participation in Wah Cantt: A descriptive analysis. Academic Research International, 2(1), 599-622.

Ahmad, E., \& Hafeez, A. (2007). Labor supply and earning functions of educated married women: A case study of northern Punjab. Pakistan Development Review, 46(1), 45-62.

Amin, S. (1994, October). The poverty-purdah trap in rural Bangladesh. Paper presented at the IUSSP's Seminar on Women, Poverty, and Demographic Change, Oaxaca, Mexico.

Azid, T., Aslam, M., \& Chaudhary, M. O. (2001). Poverty, female labor force participation, and cottage industry: A case study of cloth embroidery in rural Multan. Pakistan Development Review, 40(4), 1105-1118.

Bablola, S. J., \& Akor, M. (2013). An empirical analysis of labor force participation of married women in Adamawa state, Nigeria. Journal of Emerging Trends in Economics and Management Sciences, $4(1), 1-7$.

Becker, G. S. (1965). A theory of the allocation of time. The Economic Journal, 75(299), 493-517.

Bover, O., \& Arellano, M. (1995). Female labor force participation in the 1980s: The case of Spain. Investigaciones Económicas, 19(2), 171-194.

Chamlou, N., Muzi, S., \& Ahmed, H. (2011). Understanding the determinants of female labor force participation in the Middle East and North Africa region: The role of education and social norms in Amman (Working Paper No. 31). Bologna: AlmaLaurea Inter-University Consortium.

Chaudhry, I. S., Faridi, M. Z., \& Anjum, S. (2010). The effects of health and education on female earnings: Empirical evidence from district Vehari. Pakistan Journal of Social Sciences, 30(1), 109-124.

Ejaz, M. (2007). Determinants of female labor force participation in Pakistan: An empirical analysis of PSLM (2004-05) micro-data [Special edition]. Lahore Journal of Economics, 12, 203-223. 
Faridi, M. Z., Malik, S., \& Ahmed, R. I. (2010). Impact of education and health on employment in Pakistan: A case study. European Journal of Economics, Finance and Administrative Sciences, 18, 58-68.

Faridi, M. Z., Malik, S., \& Basit, A. B. (2009). Impact of education on female labor force participation in Pakistan: Empirical evidence from primary data analysis. Pakistan Journal of Social Sciences, 29(1), 127-140.

Faridi, Z., Sharif, I., \& Anwar, M. (2009). The socioeconomic and demographic determinants of women work participation in Pakistan: Evidence from Bahawalpur district. South Asian Studies, 24(2), 351-367.

Faridi, Z., Sharif, I., \& Malik, S. (2011). Why women are self-employed: Empirical evidence from Pakistan. International Journal of Economics and Finance, 3(1), 199-207.

Georgellis, Y., \& Wall, H. J. (2005). Gender differences in self-employment. International Review of Applied Economics, 19(3), 321-342.

Gronau, R. (1977). Leisure, home production and work: The theory of the allocation of time revisited. Journal of Political Economy, 85(6), 1099-1124.

Hafeez, A., \& Ahmad, E. (2002). Factors determining the labor force participation decision of educated married women in a district of Punjab. Pakistan Economic and Social Review, 40(1), 75-88.

Kazi, S., \& Raza, B. (1991). Duality of female employment in Pakistan. Pakistan Development Review, 30(4), 733-743.

Khadim, Z., \& Akram, W. (2013). Female labor force participation in formal sector: An empirical evidence from PSLM (2007-08). Middle East Journal of Scientific Research, 14(11), 1480-1488.

Khan, R. E. A., \& Khan, T. (2009). Labor force participation of married women in Punjab (Pakistan). Journal of Economic and Social Research, 11(2), 77-106.

Killingsworth, M. R., \& Heckman, J. J. (1986). Female labor supply: A survey. In O. Ashenfelter \& R. Layard (Eds.), Handbook of labor economics (chap. 2). Amsterdam: Elsevier. 
Kozel, V., \& Alderman, H. (1990). Factors determining work participation and labor supply decisions in Pakistan's urban areas. Pakistan Development Review, 29(1), 1-17.

Le, A. T. (2000). The determinants of immigrant self-employment in Australia. International Migration Review, 34(1), 183-214.

Maglad, N. A. (1998). Female labor supply in Sudan (Special Paper No. 30). Nairobi: African Economic Research Consortium.

Mincer, J. (1962). Labor force participation of married women: A study of labor supply. In H. G. Lewis (Ed.), Aspects of labor economics (pp. 63-106). Princeton, NJ: Princeton University Press.

Mincer, J., \& Polachek, S. (1974). Family investments in human capital: Earnings of women. Journal of Political Economy, 82(2), 76-108.

Naqvi, Z. F., \& Shahnaz, L. (2002). How do women decide to work in Pakistan? Pakistan Development Review, 41(4), 495-513.

Nasir, Z. M. (2002). Returns to human capital in Pakistan: A gender disaggregated analysis. Pakistan Development Review, 41(1), 1-28.

Pakistan Bureau of Statistics. (2012). Pakistan employment trends 2011. Islamabad: Author.

Sackey, H. A. (2005). Female labor force participation in Ghana: The effects of education. Nairobi: African Economic Research Consortium.

Tansel, A. (2002). Economic development and female labor force participation in Turkey: Time series evidence and cross-province estimates (Working Papers in Economics No. 01/05). Ankara: Economic Research Center. 